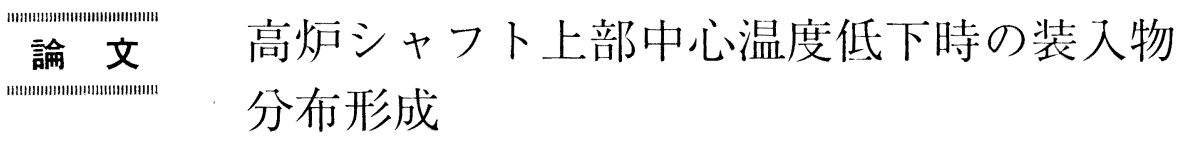

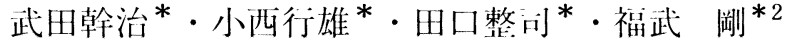

\title{
Burden Distribution in Case of Low Gas Temperature at the Center of Upper Shaft of Blast Furnace
}

Kanji Takeda, Yukio Konishi, Seiji Taguchi and Tsuyoshi Fukutake

\begin{abstract}
Synopsis :
Lowering of gas temperature at center of upper shaft was observed by decreasing sinter ratio in Mizushima No. 4 blast furnace and the stable operation was disturbed.

The burden distribution in case of the low gas temperature at center has been studied through quantitative analysis of the furnace operation data and model experiments. The ore layer collapse during ore charging was observed by the scale model experiments. The ore layer collapse could be treated quantitatively by use of a simulation model adopting a theory on the stability of the piled layer. The stability of ore layer was discussed by the model study in terms of operation variables, such as ore diameter, throat gas velocity and bell stroke. The results revealed that decrease in bell stroke and bell descending velocity could effectively prevent the burden distribution in case of low gas temperature at center.
\end{abstract}

Key words : blast furnace ; modelling ; simulation ; burden distribution ; gas ; temperature.

\section{1. 緒}

言

高炉の安定操業，低コスト操業を行う場令，装人物分 布制御により炉内の融着帯形状を適正に維持することは 不仃欠である。烜内の融着带形状を推走する指標として シャフトゾンデ，吙ロゾンデの温度，ガス成分分乕が用 いられている. 温度や CO ガス利用率の半徍方们の分 布から中心流, 㓮辺流を判断しムーバブルアーマー (MA) の位㯰，ベルレス装入装置の旋回シュートの傾動 パターンを変えることにより装入物の半往力们分布を調 整している.

通常の操業方法では, シャフトゾンデの温度は炯们 部で最高となる。ところが, 水泉 4 高炕に扔いて, 減产 操業下で焼結鉱配今比を低下させたところ，上部シャフ トゾンデ中心温度が極度に低下する分布（以下中心温度 低下型装入物分布と呼ぶ）が現れ始めた。

通常の分布から中心温度低下型装入物分布への移行が 短時閒で完〕し, 中開段階が在存しない等の中心温度低 下型装入物分布の特徽から，この分布の形成の原她分 布の形成過程における装入物層の不安走化にあると推祭
されたが，その機構は明らかではなかつた。

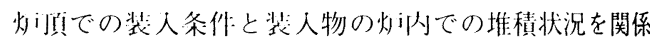
づけるために，装人物分仍模型尤験による実験绖的な研 究から堆䅡型形成のメカ二ズムの研究まで多くの研

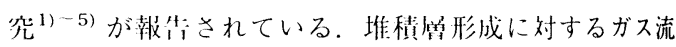
れの影響に在目した研究により，杉川ら²)は装人物表面 傾斜伯がガス流速の堌㞦とともに減少し，最少流動化開 始速度で零になることを悻斯している。また，西尾ら は，鉱装人畹に中心部ガス流速が增加し，下層のコー

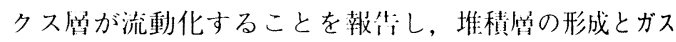
流れの相4.作用の重䓨性を強調している，堆積層，特に

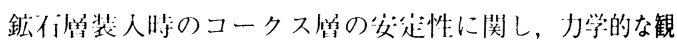

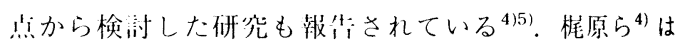

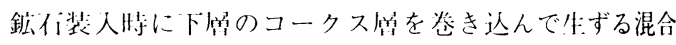
鱼莗を等験的に求め，装人物の落下エネルギーを用いて 起量化している。我，奥野ら ${ }^{5)}$ は、コークス層の崩れ を土質力学:で使われている斜面の崩壊理論6)を用いて解 析し，鉱嗬重によつて生ずるすべり線に汾つてコーク スが中心户们へ移行する機構を提案している.

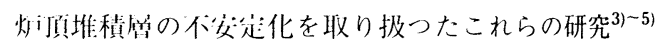

*2 川崎製鉄(株)鉄鋼研究渐 I. 博 (Iron \& Steel Research Laboratories, Kawasaki, Steel Corp.) 


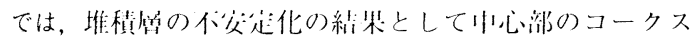
層厚が增玑して扮り，中心部の㴓度はト多すると考えら れる。このことは，中心温度低卜型装人物分们の形成機

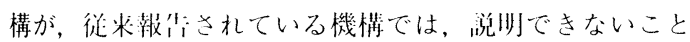
を亦している。

浴銑コストを低減させるために，しばしば烷䋽銷此を

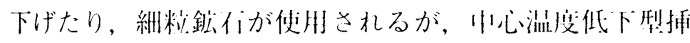
人物分们はこのような埸尽に発件し，スリップ指数の堌

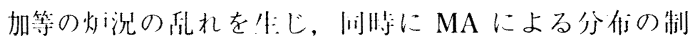
御性を低下させる。本政の目的は，中心温度低下型装人

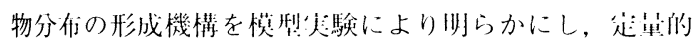
に評価できるモデルを作成し，中心温度低卜型装人物分

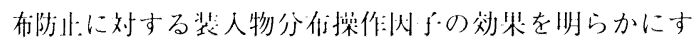
ることにある。

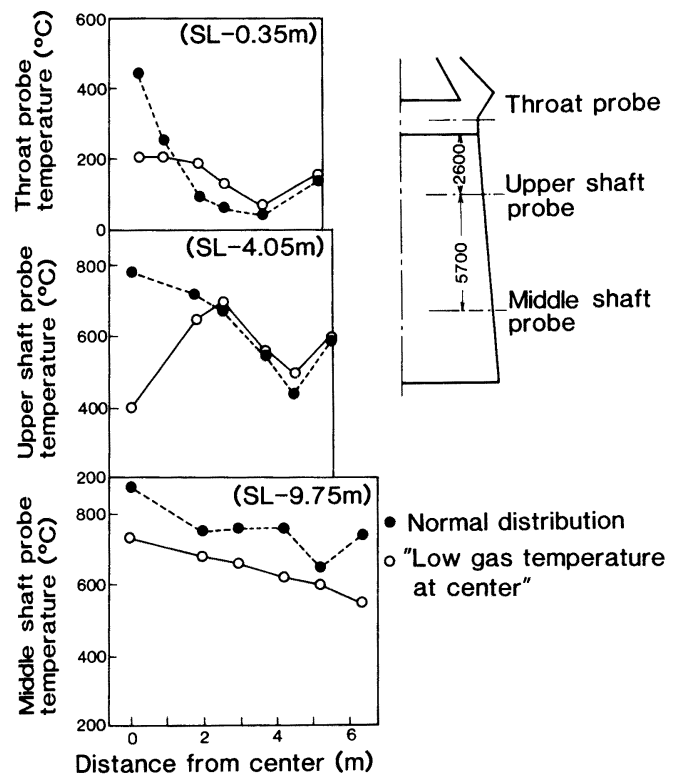

Fig. 1. Typical temperature distribution of the type of low gas temperature at center (Mizushima No. $4 \mathrm{BF})$.

\section{2. 中心温度低下型装入物分布の特徵}

中心温度低下型装人物分布の特徽である半径才问の温 度分布を，吙口部，シャフト部，シャフト中部の各位置 でFig. 1 に亦す。通常時と比較して以下の点が恭なる.

( 1 ) 吙吅ゾンデ中心温度が低下し, 㓮辽部温度が上昇 し、平圳な温度分布となる。また，上部シャフトゾンデ 巾心温度がその調网に比較して著しく低下し，極端な場 介には $200^{\circ} \mathrm{C}$ 前後になる.

( 2 ) 1: 部シャフトゾンデの中心温度が低いにもかかわ

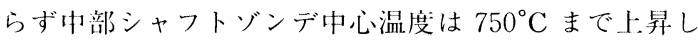
ている.

( 3 )Fig. 2 に示すように, 中心温度低下型装人物分 仰の場今には，装入物表百傾斜角が低下し，中心部が平 圳な装人物表而形状を亦す。

(4)通常の装入物分布から中心温度低下型装入物分布 への移行は数チャージ（約 $1 \mathrm{~h}$ ）内で完厂する。また, 屾者の中閏的な分布を形成することはなく，離散的な変 化をホす.

（5）中心温度低下型分布の発生に対する焼結鉱比の影 摂を Fig. 3 に示す。焼結鉱比 $70 \%$ 以下で上部シャフ トゾンデ中心温度が低下し中心温度低下型装入物分布と なつている.

(6)減磨に伴つて焼結鉱品質の規格を緩和した時や, ヤード保管焼結鉱を使用した時等で焼結鉱粉率が上昇し た時に中心温度低下型分布が発生する。

中心温度低下型装入物分布時にはスリップ指数の増加 やガス利用率の低下等の乱れが発生する。また，従来の ガス分布管理範囲から外れた分布であり，MAによる分 布の制御性が低下するという問題が生じていた。

中心温度低下型装入物分布の場合の上部シャフトゾン デの温度分布は，中心部の熱流比が 1.0 以上であるこ とを示している7). また, 高熱流比にもかかわらず中部 シャフトゾンデ中心温度が上昇しており, 融着带頂層位。 㯰が，上部シャフトゾンデ温度分布から類推されるほど 低下していないことを示している. 中心部での高熱流比 は，鉱石/コークス $(\mathrm{O} / \mathrm{C})$ の上昇より装入物粒径低下

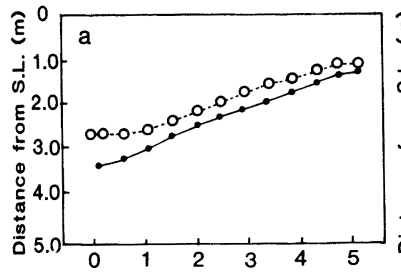

Distance from center $(\mathrm{m})$

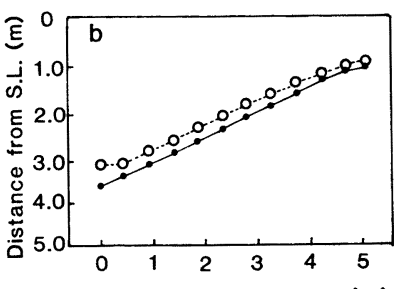

Distance from center $(\mathrm{m})$
- Normal distribution

o.... "Low gas temperature at center"

a : Surface profiles of ore

b : Surface profiles of coke

Fig. 2. Comparison of the surface profiles of burden measured with mechanical profile meter. 


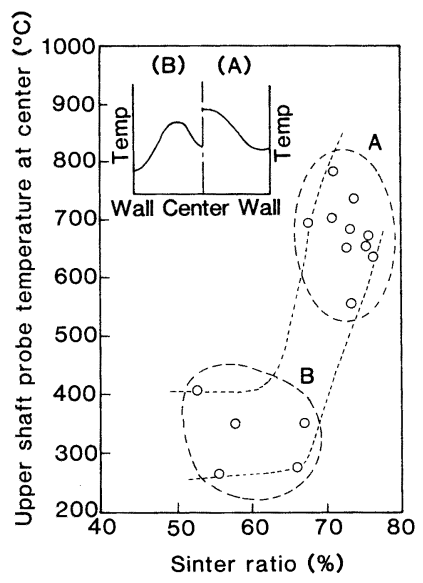

Fig. 3. Effect of sinter ratio on the temperature distribution of upper shaft probe (Mizushima No. $4 \mathrm{BF})$.

等による通気抵抗の上昇に起因していると考えられる。 また, 装入物表面形状の变化, 短時間での離散的な変化 という中心温度低下型装入物分布の特徽は, その形成過 程に装入物の流動化, 堆積層の崩れ簿の堆積層の不莯”起 化が関与していることを示している.

鉱石装入時のコークス穈の流動化に関して西尾ら ${ }^{3)}$, 成田ら ${ }^{8)}$ の報告がある。鉱不層の通気抵抗がコークス兽 に比べて大きいため，鉱不装入過程で中心部コークス層 にガス流が集中し，中心部のコークス䓟が流動化する。 流動化により中心部にコークスのみからなる層が形成さ れ，中心部のコークス層が誛化することを報告してい る.コークス層の流動化は表百形状に着目すると中心温 度低下型装人物分布と似ているが, コークス層の流動化 が起こると中心部の熱流比は逆に低下する点が異なる. また，鉱石装人時のコークス層の層崩れに関しては，奥 野らの報告 ${ }^{5)}$ があるが，コークス層の層崩れにより中心 部の熱流比が低下する点で中心温度低下型分布の形成機 構を説明できない。 中心温度低下型装人物分布は，その 特徵を従来報告されている堆積機構では説明できないた め，モデル実験により堆積機構を検討した。

\section{3. 中心温度低下型装入物分布形成機構のモデル 化}

\section{$3 \cdot 1 \quad 1 / 20$ 半裁模型実験}

中心温度低下型装入物分布の形成過程を水島 4 高炉 $1 / 20$ 半裁装入物分布模型 ${ }^{9}$ (Fig. 4) を用いて検討した。

Table 1 に示す実験条件で鉱石とコークスを 2 回ずつ装

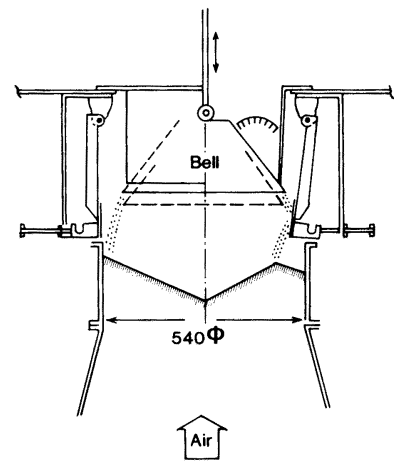

Fig. 4. Schematic diagram of $1 / 20$ scale experimental apparatus of Mizushima No. 4BF.

Table 1. Experimental charging conditions.

\begin{tabular}{|c|c|c|}
\hline Item & \multicolumn{2}{|c|}{ Experimental value } \\
\hline $\begin{array}{l}\text { Basic charging } \\
\text { conditions }\end{array}$ & $\begin{array}{l}\text { 1) MA sequence } \\
\text { 2) Coke base } \\
\text { 3) OC } \\
\text { 4) Stock level } \\
\text { 5) Bell stroke } \\
\text { 6) Bell descending time } \\
\text { 7) Blast volume }\end{array}$ & $\begin{array}{l}:\left|C_{5} \downarrow 0_{5} \downarrow\right| \\
\vdots 4.6 \mathrm{~kg} \mathrm{ch} \\
\vdots 3.5 \\
\vdots 71 \mathrm{~mm} \\
\vdots 38 \mathrm{~mm} \\
\vdots 12 \mathrm{~s} \\
: 1.3 \mathrm{Nm}^{3} \mathrm{~min}\end{array}$ \\
\hline $\begin{array}{l}\text { Experimental } \\
\text { conditions }\end{array}$ & $\begin{array}{l}\text { 1) Fine ore ratio } \\
\text { 2) } \mathrm{MA} \text { sequence } \\
\left|\mathrm{C}_{5} \downarrow O_{8} \downarrow\right| . \mid \mathrm{C}_{5} \downarrow \mathrm{O}_{10} \\
\text { 3) Bell stroke } \\
\text { 4) Bell descending time } \\
\text { 5) Two batch charge of }\end{array}$ & $\begin{array}{l}; 1,5,7,10 \% \\
\vdots\left|C_{5} \downarrow O_{4} \downarrow\right|,\left|C_{5} \downarrow O_{6} \downarrow\right| \\
\left|C_{5} \downarrow O_{12} \downarrow\right| \cdot\left|C_{0} \downarrow O_{12} \downarrow\right| \\
\vdots 38,25,18 \mathrm{~mm} \\
\vdots 12,20,30 \mathrm{~s} \\
\left.; C_{5} \downarrow()_{5} \downarrow\right)_{5} \downarrow \mid\end{array}$ \\
\hline
\end{tabular}

$\left|C_{n} \downarrow O_{m} \downarrow\right|$; Subscript $n$ and $m$ denote MA position of coke and ore, respectively I denotes dump charge from large bell

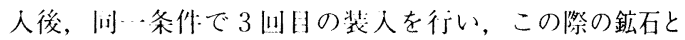

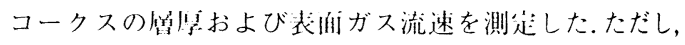

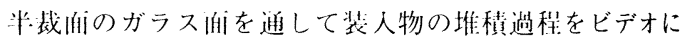
收録する尖験では観繁や解析を谷㔠にするためコークス

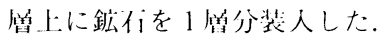

鈗们中の粉泫 $(-0.21 \mathrm{~mm}$ の制令）を変えることによ り鉱れ门盆の通父性を变化させて行つた装人奏験の結果を Fig. 5 に亦す。粉浨 1\%の場介には中心部のガス流速 の人きい通带の分优が得られるが，粉率 $7 \%$ 以上では， 中心での流速が低下し，䀧次元半徍 0.2 の位㯰にガス 流速のピークが現れる。间時に，中心部の鉙石の表面形 状が壮步!とり，赺灯の中心温度低下型装人物分布と類 似の分布が得られる。

半裁のガラス闬を通してビデオ観祭した鉱石層の堆積 挙動を Fig. 6 に亦す。通常時の場令，大ベルから排出 された鉣不は，灯谁近傍に一時堆積し，その後中心に向 かつて流れ迄む。鉱装人中の鉱僧の表面傾斜角は最 終的に形成される表阳倾斜的より数度大きく，装入中は ほぼ一分である。中心渭度低下時の鉱不噌の堆積挙動は, 


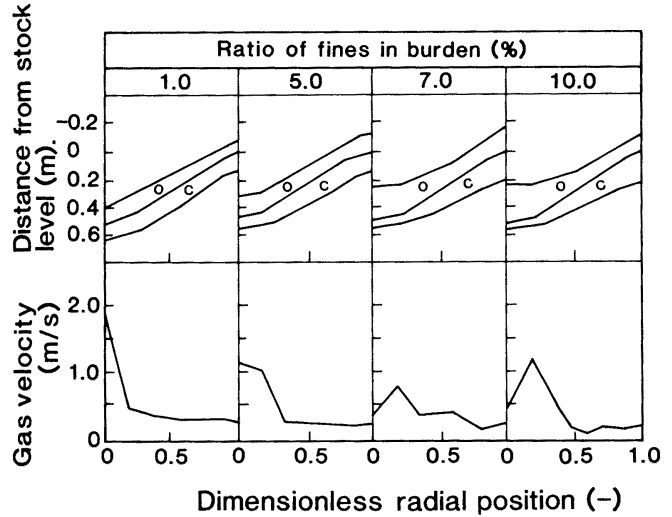

Fig. 5. Effect of fine ore ratio on the burden distribution.

i) Movement of ore layer to the furnace center

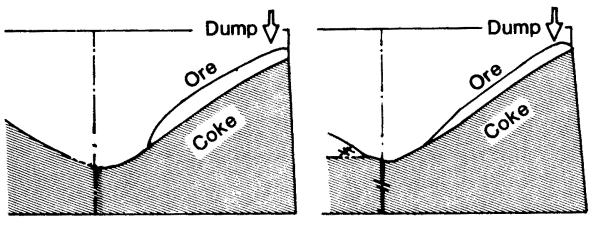

ii) $3.4 \mathrm{sec}$ after starting of the charge
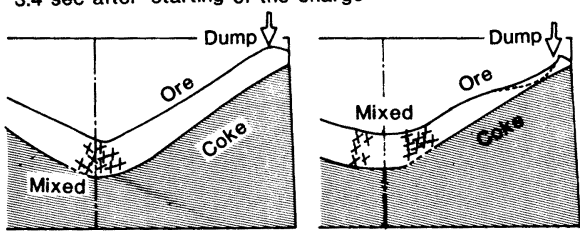

iii) Final profile of ore layer
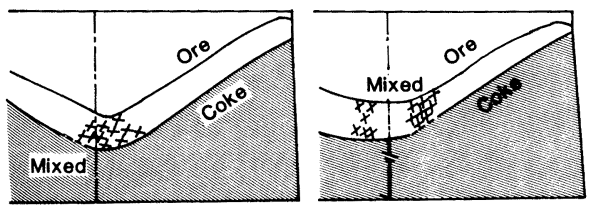

a) Normal distribution

b) Low gas temperature at center

Fig. 6. Comparison of ore layer change through charging between a) normal distribution and b) low gas temperature at center.

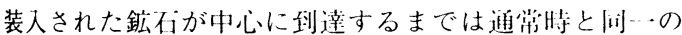

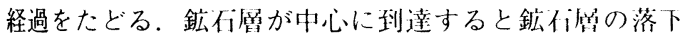
位置を起点にして鉣俯が崩れ始め，中心部の鉱们量が 増加する。斜面内鉣不は壁側に洲留することなく，诂 ちに中心に流れ込み，中心部から炏壁に问かつて順に堆 積し，層厚を增していく，鉱们装人時にコークス腐日体 も崩れることが多く，通常時と比較して中心部に形成さ れる混合層領域は增大寸る。以上の装人物の堆䅡举動か

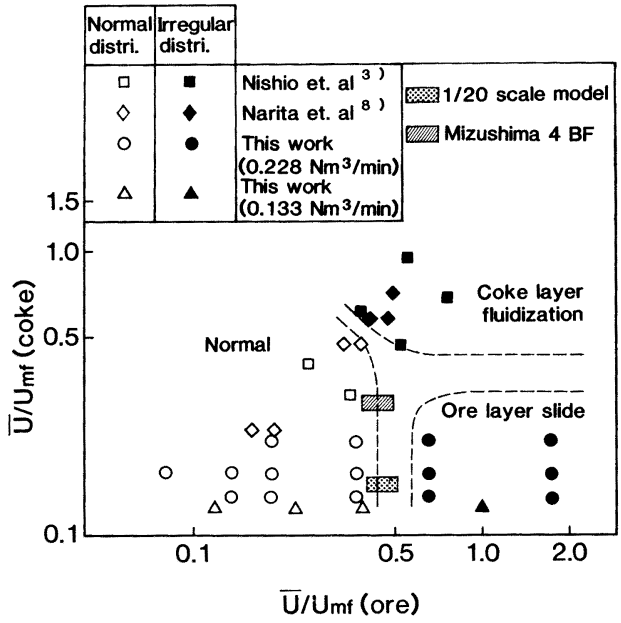

Fig. 7. Effect of ratio of superficial velocity and minimum fluidization velocity on characteristics of layer formation.

ら，鉱不装入途中に鉱不曆が層崩れを起こし，灯壁部に 堆積していた紐粒原料が中心に流れ込み中心部の通気性 を低下させることが中心温度低下型装人物分布形成の直 接の原因であると推祭される。

\section{$3 \cdot 2$ 鉱石層崩れに対する鉱石粒径の影響}

鉣不装入時の層崩れに対する鉱不層の通気抵抗の影響 を定量的に把握するため，実験执よび解析が容易な粒度 範用の狭い鉱石を用い， “次元矩型（200 mm 幅 $\times 100$ $\mathrm{mm}$ 奥行き)の装入物分布モデルを用いて実験を行つた。 送風量 $\left(0.228 \mathrm{Nm}^{3} / \mathrm{min}, 0.133 \mathrm{Nm}^{3} / \mathrm{min}, 0.088 \mathrm{Nm}^{3} / \mathrm{min}\right.$ の 3 水準), コークス粒往拐よび釷石粒径を変更し, 鉱 不の層崩れに対する各要因の影響を調查した。鉱石の層 崩れに刘し，ガスの浮力が主要な要团になつていると考 之, 各粘子の最小流動化速度 $\left(U_{m f}\right)$ と断面平均流速 $\bar{U}$ の比を用いて実験絬果を整理し Fig. 7 に示した。また， コークスの流動化に関する従来の報告3)8 均により平均粒往を算出し，著者が実験的に求めた焼結 鉱とコークスの平均粒徍と最小流動化速度の関係式から 齐粒子○の最小流動化開始速度を求め, Fig. 7 に示した。

鉱闪層の $\bar{U} / U_{m f}$ が 0.5 以上, コークス層の $\bar{U} / U_{m f}$ が 0.1 ～ 0.3 の領域で鉱石の層崩れが顕著である。ガス 流速が等しい場令, $\bar{U} / U_{m f}$ の増加は $U_{m f}$ の低下, 粒径 低下等による通気抵抗の増大を意味する。一定のガス流 速のもとで鉣不粒径を低下させた場命，コークス層の粒 径が小さい場命 $\left(\bar{U} / U_{m f}(\right.$ coke $\left.)>0.5\right)$ にはコークス靨 の流動比が，コークス層の粒径が大きい場命 $\left(\bar{U} / U_{m f}\right.$ $($ coke $)<0.3)$ には鉱不層の層崩れが発生する。また両 


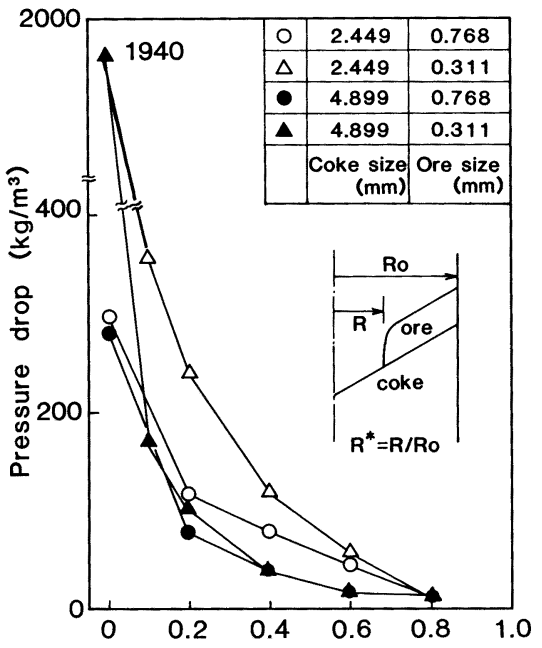

Radial position of the edge of ore layer $\mathrm{R}^{*}$ (dimensionless)

Gas velocity $=0.207 \mathrm{~m} / \mathrm{s}, 25^{\circ} \mathrm{C}$

Fig. 8. Calculated results of pressure drop change across the ore layer as it proceeds toward furnace center during charging.

者の境界では，層崩れとコークスの流動化を区別するの が困難となる。また水島 4 高烟の場令，粉率の上昇によ り鉱石層の層崩れの発生する領域にある.

装入途中の鉱石層とコークス層へ加わるガスの浮力を 実測することが困難なため，二次元ガス流れモデル10) を用いてガス浮力に対する粒径の影響を検封した。コー クス層上に鉱不層が装入された場令，鉱不層が中心す们 へ流れ込む際のガス流れの変化を，ガス流れの分常，装 入物表面で等压という伡定を設けて検时した。Fig. 8 に中心から鉱石層先端までの距離 $R$ と鉱不層に加わる ガス浮力の平均值との関係を示す。コークス粒往が大き い場今（脳中○人），鉱不層が中心に到達するまでは， ガス浮力の上昇は小さく，鉱石層が中心に到達してはじ めて鉱石粒径に応じたガス浮力を生ずる，鉱不の粘径が 小さく，この際に生ずるガス浮力が大きい場众（似中二） には，鉱不層が不安定となり，層崩れを発牛させる。

コークス粒径が小さく，鉱石粒径も小さい場合(伙中 $\triangle)$, 鉱石層のガス浮力は装入途中で急激に增加する。 鉱石層へのガス浮力の増加は，同時に露出しているコー クス層への浮力の増加を意味し，コークス層の自重をガ ス浮力が超えると露出コークス層が流動化して中心部に コークス単味層を形成する。また，コークス単味層の形 成により，ガス浮力のそれ以上の上昇が妨げられ，鉱不 層崩れは発生しなくなる.

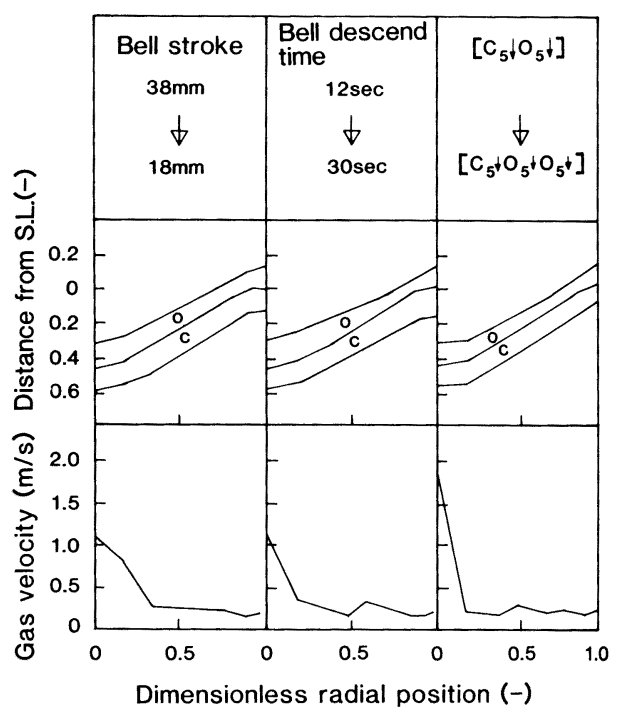

Fig. 9. Effect of charging conditions on the distribution of layer thickness and gas velocity.

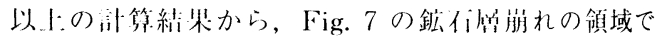

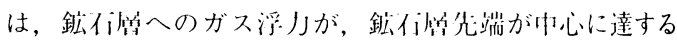

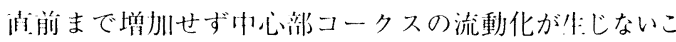

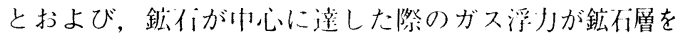

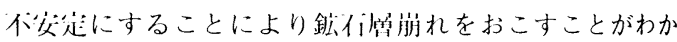
る。

\section{$3 \cdot 3$ 鉱石層崩れに対する装入条件, 焼結鉱配合比の影 響}

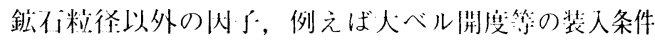

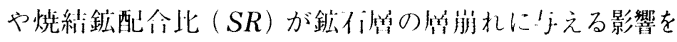

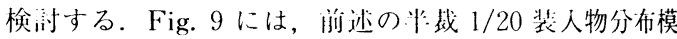
型起験装㯰を用いてそれぞれ人ベル開度綰小，大ベル開

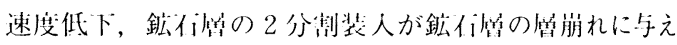
る影響をふした。 Fig. 9 にホすよよに其本条件 (Fig. 5 中の粉摔 7\%の良験）では中心㴓度低下型分布だつた ものが, ベル開度維小, ベル開速度の低下，鉱们の2 分 制装人により円心部のガス流速が聂人となる通常の分布

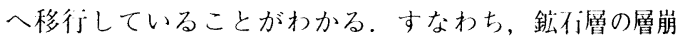
れは鉣不粒待の他に装人条作が影裂している。

\section{$3 \cdot 4$ 鉱石層崩れのモデル化}

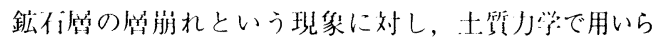
れている斜泊阙壊に関する解析于法 ${ }^{6)}$ 適用し，力の釣 今心に対する川损众，装人物の装人条作，焼結鉱の影

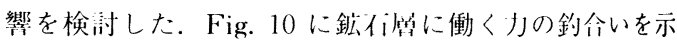

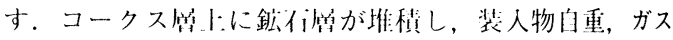




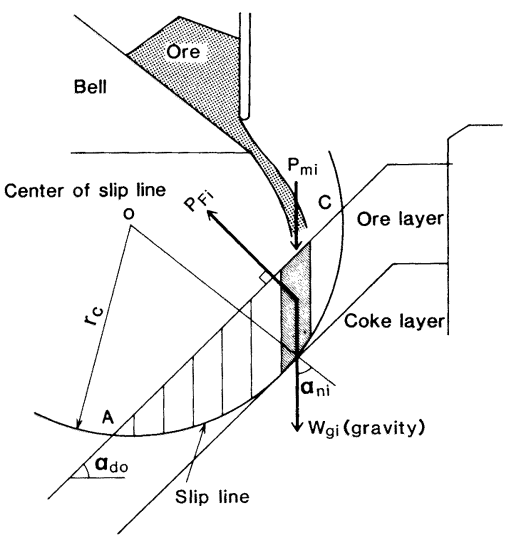

$P_{m}$ : Momentum change of charged ore $P_{F}$ : Pressure drop of gas

Fig. 10. Schematic diagram on calculation method of safety factor of ore layer.

浮力，装人物の落下に伴う力が鉣们鼻に加わり釣り介つ

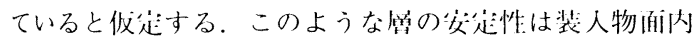

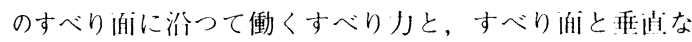

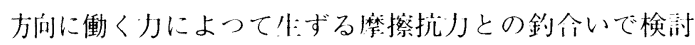

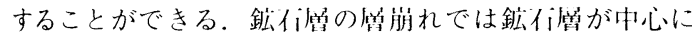

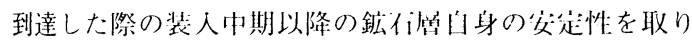

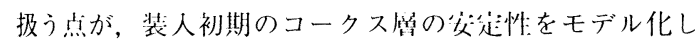
た奥野ら と) と異なる器である。

Fig. 10 にホすすように0を中心とした游瓜 $\mathrm{AC}$ をすべ り面として仪并した。クーロンの法剘によればすべり陑 におけるせん断独さ $S$ は( 1 )式で!j.えられる。

$$
S=\sigma \tan \phi_{0}+C_{0}
$$

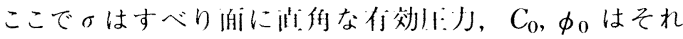
ぞれ周存な粘着力，内蔀杽擦解であり，鉣们の場令通笛 は $C_{0}=0$ である。この状態での师弧 $\mathrm{AC}$ 姠のせん断忘

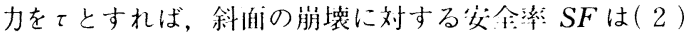
式で智義できる.

$$
S F=\underset{\tau}{\sigma \tan \phi_{0}}
$$

安全率 $S F$ は忊呱 $\mathrm{AC}$ のとりおにより種々の值が求ま る。一般にコークス算の内部摩擦角は, 鉱不層の内部摩 擦角に比べて 5〜6度大きい11)。また，灯内での鉱不， コークスの堆積角の差は約 2 度と小さいため, コークス 層が安定層として作用するものと考え，ここではすべり 面をコークス層に接する叫弧で近似した。従つてすべり 面は 0 点を仮定すると，コークス表酒に接する川弧で一 意的に与えられる．中心垈０の位䁇を少しずつ変えてけ 弧を仮定し，そのたびごとに发全摔 $S F$ を湖算する。こ
のうち, 妾全率が最小となるすべり面を求め, このとき の $S F$ が1より小さい場命に斜面が不安定となる.

円弧すべり面に沿うせん断力 $\tau$ を計算するため, Fig. 10 に示すようにすべり面を鉛直方向に多数の帯状要素 に分割し，各要素に働く力を計算し，全体で合計する. 要素 $i$ についてすべり面に平行なせん断力 $\tau_{i}$ は( 3 )式, 酒に垂唒な有効力 $\sigma_{i}$ は( 4$)$ 式で与えられ, 各要素につ いて和を求めると, 安全率 $(S F)$ として( 5$)$ 式が得られ る.ただ， $P_{m i}$ は装入位置のみで值を持ち, その他で は零である.

$$
\begin{aligned}
& \tau_{i}=\left(W_{g_{i}}+P_{m i}\right) \sin \alpha_{n i}+P_{F i} \sin \left(\alpha_{d o}-\alpha_{n i}\right) \\
& \sigma_{i}=\left(W_{g_{i}}+P_{m i}\right) \cos \alpha_{n i}+P_{F i} \cos \left(\alpha_{d o}-\alpha_{n i}\right) \\
& S F=\frac{\sum_{i} \sigma_{i} r_{c} \tan \phi_{0}}{\sum_{i} \tau_{i} r_{c}}
\end{aligned}
$$

大ベルから落下する装入物により斜面に与えられる力 を求めるには大ベルから落下する単位幅当たりの装入物 流量 $F$ と, 速度 $u$ を知る必要がある. 装入物斜面と装 人物との友発係数を $e_{n}$ とすると, 装入物面に加わる力 として( 6$)$ 式が得られる.

$$
P_{m}=\frac{u\left(1+e_{n}\right) F}{g_{c} W_{d}}
$$

落下時の装入物の連動を観察した結果, 垂直方向の装 人物のはね上がりがほとんど認められないので $e_{n}=0$ と仗走した。また単位幅当たりの装入物流量 $F$, 落下 媔 $W_{d}$ は実験により求めた.

\section{$3 \cdot 5$ 層崩れモデルの計算結果}

鉱石層崩れシミュレーションに用いた条件を Table 2 に示す．既述のように，すべり面の断面形状をコークス 穈に接する円弧と仮定しているため, 円弧の中心 0 の位 置によりすべり面は一意的に決まり，円弧の中心 0 の位 㯰に対伈して安全率が求められる．Fig. 11 には，0の 位置に対伈した安全率の分布を示す，すべりは最もすべ りやすい面で起こるため, 安全率の最小值ですべりの有 無と位置が判断でき，最小值が 1 を超えておればすべり を起こさない. Fig. 11 の例では, 最小安全率を有する

Table 2. Simulation condition for ore layer collapse.

\begin{tabular}{l|cc}
\hline & $\begin{array}{c}\text { Rectangular } \\
\text { model }\end{array}$ & $\begin{array}{c}\text { Mizushima } \\
4 \mathrm{BF}\end{array}$ \\
\hline Bell diameter $(\mathrm{m})$ & 0.141 & 4.025 \\
Bell descending speed $(\mathrm{m} / \mathrm{s})$ & 0.020 & 0.0633 \\
Bell angle $\left({ }^{\circ}\right)$ & 45 & 53 \\
Throat diameter $(\mathrm{m})$ & 0.200 & 5.3 \\
Surface angle of ore $\left({ }^{\circ}\right)$ & 35 & 35 \\
Internal friction factor of ore $(-)$ & 1.0 & 1.0 \\
Pressure drop in ore $\left(\mathrm{kgf} / \mathrm{m}^{3}\right)$ & 300 & 300 \\
\hline
\end{tabular}




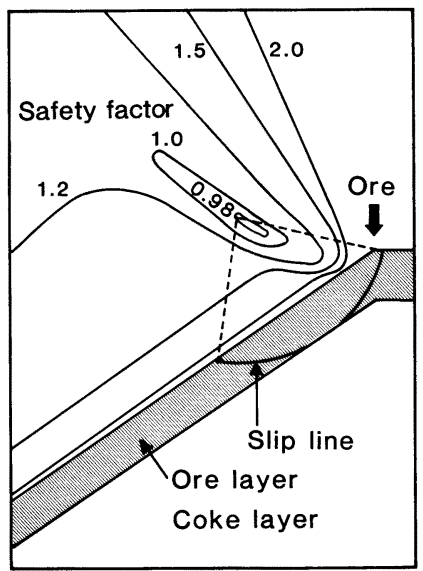

Fig. 11. Change of safety factor for ore collapse with change of the location of the center of slip line arc.

すべり面は，装入物落下位置を起点として，コークス層 に接する円弧である。このすべり面の形状は，Fig. 6 に模式的に示した鉱石層崩れの形状に類似している.

このようなモデルを用いて層崩れの発生限界を把握す るためには，鉱石装入過程での表面形状，装入物の内部 摩擦角を定量的に求める必要がある。しかし，本報告で は解析を容易にするため, 表面形状, 内部摩擦角を Table 2 に示す一定值にし, 装入条件, 圧力損失が鉱不 の層崩れに与える影響について検討した。

Table 2 に示した条件で, 压力損失のみを変更した場 合の安全率の変化を Fig. 12 に示した. 圧力損失の増加 に伴い安全率が低下し鉱石層が不安定になることを示し ている. 2 次元ガス流れモデル ${ }^{10)}$ を用い Fig. 8 の条件 で鉱石層が中心まで到達した時の粒径と压力損失の関係 を求め, Fig. 12 内に示した. 粒径の低下に伴い安全率 が低下し，鉱石の粒径低下，粉率の増加により鉱不層の 層崩れが起こることがわかる.

大ベル開度変更による装入物の落下運動量の変化が, 鉱石層崩れに与える影響について Fig. 13 に示した。大 ベル開度の低下により装入物の排出流量が低下し, 鉱不 層の層崩れが防止できることを示している. Fig. 9 に 示した, 大ベル開度の低下, 大ベル開速度の低下により, 中心温度低下型装入物分布の生成が防止できるという実 験結果と, Fig. 13 の計算結果は一致している.また, 鉱石層の 2 分割装入も装入物の排出量の低下という点で 中心温度低下型装入物分布の防止:に効果があることは谷 易に理解できる。

鉱石の層崩れに対する種々の要因の影響を最小安全率

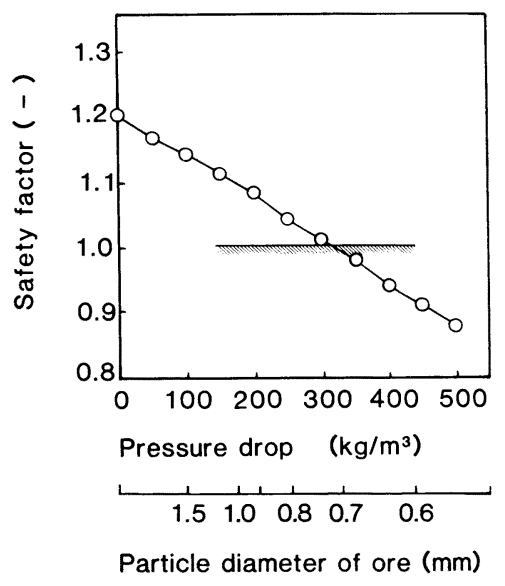

Fig. 12. Change of safety factor of ore layer collapse with the pressure drop.

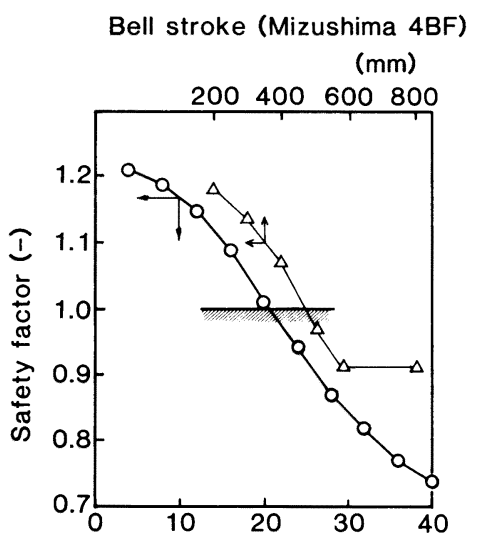

Bell stroke (rectangular model) $(\mathrm{mm})$

Fig. 13. Effect of bell stroke on safety factor of ore layer.

の変化量という形で定量化し Table 3 に示した。 2 次 元ガス流れモデルを用いて鉣不粘往, 火吅部のガス流速 の変化に伴う鈗不層の川方損失の变化を計算し, 最小安 全率の变化量を計算した。通产の操業で变更できる範囲 で変化させた备因与の最小茹全率の変化量でみると, 新 たな分布制御手段である大ベル開度，開速度 ${ }^{12)}$ が中心 温度低下型分布の防止:に効果的であることがわかる。ま た，最小安全率が1.0以下になると鉱不の層崩れが発 生するため, 最小㚣全率 1.0 近傍での変化は変化量と

しては小さくとも軽視することができない.

中心温度低下型装入物分布は焼結鈗比 $70 \%$ 以下で顕 著に発生している. Fig. 14 に，焼結鉱配合比が半径方 向の粒度偏析指数および，堆積層に一定の振動を加えた 
Table 3. Effect of operational variables on ore layer collapse.

\begin{tabular}{l|c}
\hline \multicolumn{1}{c|}{ Operational variable } & Change of safety factor $(-)$ \\
\hline $\begin{array}{l}\text { Ore diameter } \\
11.8 \mathrm{~mm} \rightarrow 12.2 \mathrm{~mm}\end{array}$ & 0.030 \\
\hline $\begin{array}{l}\text { Throat gas velocity } \\
0.90 \mathrm{~m} / \mathrm{s} \rightarrow 0.85 \mathrm{~m} / \mathrm{s}\end{array}$ & 0.038 \\
\hline $\begin{array}{l}\text { Internal friction angle } \\
40 \rightarrow 41\left(^{\circ}\right)\end{array}$ & 0.026 \\
\hline $\begin{array}{l}\text { Bell stroke } \\
760 \mathrm{~mm} \rightarrow 360 \mathrm{~mm}\end{array}$ & 0.19 \\
\hline $\begin{array}{l}\text { Bell descending time } \\
12 \mathrm{~s} \rightarrow 30 \mathrm{~s}\end{array}$ & 0.11 \\
\hline $\mathrm{C} \downarrow 0 \downarrow \rightarrow \mathrm{C} \downarrow 0 \downarrow 0 \downarrow$ & 0.08 \\
\hline
\end{tabular}

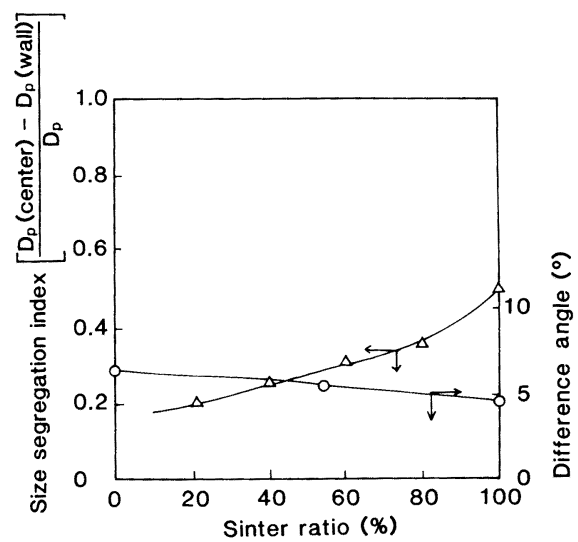

Difference angle: Change in angle of repose by the vibration

Fig. 14. Effect of sinter ratio on size segregation and difference angle.

際の堆積角の変化をボす差角に及ぼす影響を亦す。塊鉱 石は，焼結鉱と比較して䊉度範䎴が狭いため，焼結鉣の 配合率の低下により中心に到達する人塊の量が減少して いる。このため，焼結鉣比の低下に伴い往方问の粒度偏 析が減少し，中心部のガス流が抑制されるため鉱不層平 均の压力損失が増加, 層崩れを起こしやすくなつている

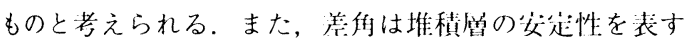
指数であるが，烧結鉱比の低下に伴い差的が增大し，鉱 石層が不安定になると考えられる。镨角とモデルで用い ている内部摩擦角の関係，拉よび尖灯粒一の差角，内部 摩擦角に対する烧結鉱比の影響が明らかになつていない ため，鉱石層崩れに対する焼紡鉱比の影響を足量的に説 明することは，今後の課題として残されている.

\section{4. 結言}

シャフト上段ゾンデ中心温度が低下する中心温度低下 型装入物分帅の形成メカニズムの検㴻を尖为门の操業解
析，模型実験装置により行い以下の知見を得た。

(1)鉱石装入時の鉱石層自身の層崩れにより中心温度 低下型装入物分布が形成される。

( 2 )鉱石層内にすべり面を仮定した斜面の崩塤に関す る理論の適用により鉱石層の層崩れの発生が定量的に表 現できる。

( 3 )鉱石層の層崩れに対する装入物落下連動量, 内部 摩擦角の影響を検討し，大ベル開度，大ベル開速度，焼 結鉱比の変化と中心温度低下型装入物分布の発生との対 忍を説明することができた。

（4）また，鉱石中粉率の増大により中心温度低下型装 入物分布の発生が顕著になるが, 大ベル開度, 開速度の 変更がその抑制に効果的であることが明らかになつた。

\section{記 号}

$e_{n}:$ 父発係数 $(-)$

$F$ : 単位幅当たりの装入物流量 $(\mathrm{kg} / \mathrm{ms})$

$P_{m}:$ 装入物の落下力 $(\mathrm{kgf})$

$P_{F}:$ ガスの浮力 (kgf)

$S F$ : 安全率 (一)

$r_{c}$ : すべり面半往 $(\mathrm{m})$

$U$ : 平均ガス流速 $(\mathrm{m} / \mathrm{s})$

$U_{m f}$ : 最小流動化開始速度 $(\mathrm{m} / \mathrm{s})$

$u:$ 落下速度 $(\mathrm{m} / \mathrm{s})$

$W_{g}:$ 装入物自重 $(\mathrm{kg})$

$W_{d}:$ 落下幅 $(\mathrm{m})$

$\phi_{0}:$ 内部摩擦角 $(-)$

$\tau:$ せんだん忍力 $\left(\mathrm{kgf} / \mathrm{m}^{2}\right)$

$\sigma$ :垂㨁忍力 $\left(\mathrm{kgf} / \mathrm{m}^{2}\right)$

$\alpha_{d o}$ : 鉱石表面傾斜角 $(\mathrm{deg})$

$\alpha_{n i}$ : すべり面傾斜角 $(\mathrm{deg})$

添之角: $i$ : 要素番等

\section{文献}

1 ) R. L. Stephenson and F. C. LANGenherg: Blast furnace, raw materials and coke oven proceedings (1953), p. 265

2 ) 杉川1 喬, 中村正和, 鵜野建夫, 原 行明: 鉄と鎙, 62 (1976), S 39

3 ) 㐾毛浩明，有山達郎: 鉄と鋼，66（1980), p. 1878

4 ) 梶原義雅, 神保高生, 上甲忠嗣, 網永洋一, 稲田隆信: 鉄と鍋，71（1985），p. 175

5 ）奥野嘉雄, 国友和也, 入田俊幸, 松崎真六: 鉄と鋼, 72 (1986), p. 783

6 ）泇.上汸義: 土質力学: (1971) [森北出版]

7 ) 武田幹治, 小西行雄, 田口整司: 学振 54 委-No. 1698 (昭和 59 年 7 月)

8 ）成田貫一, 稲葉晶一, 清水正賢, 小林 勲, 沖本憲市, 111荒太: 鉄と鋼, 66 (1980), p. 459

9 ) 小洒行雄, 浜田尚夫, 棉谷暢男: 鉄と銅, 69 (1983), $\mathrm{S} 730$

10）八木順一郎，武田幹治，大森康男: 鉄と鋼，66 (1980), p. 1888

$11) H$. Biausser, $J$. B. Guillot and $A$. Rist: Blast furnace conferance, Arles (1980), p. I. 2.1

12）汽田㚘郎，金子憲一，奥村和男，安野元造，才野光男， 浜田尚大: 川崎製鉄技報，15（1983），p. 185 